\title{
Analysis of yield stress ratio and overconsolidation ratio as parameter determination preconsolidation in eemian gyttja
}

\author{
EDYTA E. MALINOWSKA, MAREK BAJDA \\ Faculty of Civil and Environmental Engineering, Warsaw University of Life Sciences - SGGW, \\ Poland
}

\begin{abstract}
Analysis of yield stress ratio and overconsolidation ratio as parameter determination preconsolidation in eemian gyttja. The preconsolidation stress is an important phenomenon that determines the value of stress history exerted in the past on the subsoil in the geotechnical engineering. Overconsolidation ratio $(O C R)$ is one of the main criteria conditioning soil behaviour and its characteristics. Here thought, the yield stress ratio $(Y S R)$ is used to determine the value of preconsolidation stress resulting from mechanical overburden than can be changed by many post depositional processes like secondary and tertiary compressibility, cementation, aging, temperature change and others. The yield stress ratio $(Y S R)$ is defined as the relationship between vertical yield stress $\left(\sigma_{v y}^{\prime}\right)$ to the effective vertical stress $\left(\sigma^{\prime}{ }_{v 0}\right)$. The eemian gyttja was used as a foundation in the engineering construction. In practical geotechnical engineering, evaluation of stress history is usually based on the overconsolidation ratio $(O C R)$. The yield stress ratio (YSR) was used in the laboratory as one of the basic parameters for the geotechnical design of the structure. To know the relation between geological background, history and mechanical behaviour in long-time process of the soil aims a knowledge that can help engineers who often have to predict soil behaviour based upon the soil geological history and a few geotechnical data. In order to evaluate the yield stress ratio of eemian gyttja it is necessary to restore this soft, organic soil as much as possible to the in situ conditions. The laboratory tests were used to determinate the vertical yield stress and then the yield stress ratio. The laboratory tests were made in the
\end{abstract}

automatic oedometer and the in situ tests were carried out on the dilatometer test (DMT). The comparison between the determination the yield stress ratio of eemian gyttja from the laboratory and the overconsolidation ratio from in situ test has been done. The studies have shown that the values of the overconsolidation ratio determinate from the laboratory tests are a little higher than determinate from the in situ tests.

Key words: yield stress ratio, overconsolidation ratio, eemian gyttja

\section{INTRODUCTION}

The preconsolidation stress is an important phenomenon that determines the value of stress history exerted in the past on the subsoil in the geotechnical engineering. Overconsolidation ratio $(O C R)$ is one of the main criteria conditioning soil behaviour and its characteristics. Here thought, the yield stress ratio (YSR) is used to determine the value of preconsolidation stress resulting from mechanical overburden than can be changed by many post depositional processes like secondary and tertiary compressibility, cementation, aging, temperature change and others.

The overconsolidation ratio $(O C R)$ is defined as follows: 


$$
O C R=\frac{\sigma_{p}^{\prime}}{\sigma_{v 0}^{\prime}}
$$

where:

$\sigma_{p}^{\prime}$ - preconsolidation pressure;

$\sigma^{\prime}{ }^{\prime}-$ effective vertical stress.

The yield stress ratio $(Y S R)$ is defined as follows (Burland 1996):

$$
Y S R=\frac{\sigma_{v y}^{\prime}}{\sigma_{v 0}^{\prime}}
$$

where:

$\sigma_{v y}^{\prime}-$ vertical yield stress;

$\sigma^{\prime}{ }^{\prime}-$ effective vertical stress.

The term preconsolidation pressure and overconsolidation ratio should be used for the situations that we know or suppose the values of the geological history. The term vertical yield stress and yield stress ratio should be used for the "real situation" when the soil under long-time compression is noticed. In the soil that the secondary and tertiary compression is visible the yield stress ratio should be obtained.

The proper evaluation of the past effective consolidation stress in the case of natural soil subjected to a complex and difficult to reconstruct geological past often seem to be a problematic task (Stróżyk 2015). The pre-consolidation pressure value is normally determinate based on compressibility soil test and usually identified with the yield stress and found as a characteristic point on the oedometer tests, where the soil stress-strain is collapsing (Lambe and Whitmen 1977). The reduction of in situ pressure can be caused by natural geological processes (i.e. melting of glacial ice, tectonic movements, precipitation of cementing agents) or human effects (i.e. excavation). When the present effective vertical stress is less than this maximum, the soil is overconsolidated.

Szczepański (2007) indicated that the vertical yield stress is bigger than the preconsolidation pressure, because of the creep of soil or like some author says "aging of the soil" (Bjerrum and Lo 1963, Schmertmann 1991).

\section{MATERIAL AND METHODS}

In situ dilatometer test is usually used to determine the overconsolidation ratio $(O C R)$, based on empirical regional formulas (Bajda and Skutnik 2010, Lechowicz et al. 2014). In the laboratory, the preconsolidation pressure or the vertical yield stress can be obtained from the oedometer tests in long-time stress-strain characteristics. Although,Lipiński and Wdowska (2017) in the new method for evaluation of yield stress in cohesive soils indicated that the TX tests should be performed because of, among others, the disturbances can change the final results. Nevertheless, some comparison between oedometer and TX tests on undisturbed organic soils samples have been done and for a long-time process of secondary and tertiary compression excluding measurement of Skempton parameter and pore water pressure, etc. the test results were similar.

In situ investigations using DMT were performed in the "Żoliborz channel" that is located in the western part of Warsaw, where sedimentation of organic soils took place during the Eemian Interglacial. The channel is about $12 \mathrm{~km}$ long and nearly $800 \mathrm{~m}$ wide in its central part. In the "Żoliborz channel", the organic soils i.e. 
organic mud and gyttja, reach a thickness of up to $10 \mathrm{~m}$ (Fig. 1). The DMT test was made from the bottom of excavation with a depth of $5.0 \mathrm{~m}$. The calculation included the weight of excavated soil (Bajda and Malinowska 2017).

The type of soil samples, the laboratory methods and in situ methodology were described by Bajda and Malinowska (2016).

The physical laboratory tests were carried out on two undisturbed eemian gyttja's samples and included: general index tests for classification and characterization of the gyttja according to PN-EN ISO 14688 - density, grain size distribution and measurement of compressibility tests. The samples of the eemian gyttja have been retrieved from $7.2 \mathrm{~m}$ depth $(2.2 \mathrm{~m}$ below the bottom of excavation) using a Shelby sampler. The physical properties of tested samples are shown in Table 1.

TABLE 1. Index properties of eemian gyttja at the test site

\begin{tabular}{|l|c|}
\hline Physical properties & $\begin{array}{c}\text { "Skierniewicka- } \\
\text {-Wolska" }\end{array}$ \\
\hline Water content $(\%)$ & 96.0 \\
\hline $\begin{array}{l}\text { Density of soil particles } \\
\left(\mathrm{kN} \cdot \mathrm{m}^{-3}\right)\end{array}$ & 2.25 \\
\hline Bulk density $\left(\mathrm{kN} \cdot \mathrm{m}^{-3}\right)$ & 1.38 \\
\hline Dry density $\left(\mathrm{kN} \cdot \mathrm{m}^{-3}\right)$ & 0.70 \\
\hline Organic matter content $(\%)$ & 20.0 \\
\hline Initial void ratio $(-)$ & 2.28 \\
\hline Porosity $(-)$ & 0.7 \\
\hline
\end{tabular}

Source: Bajda and Malinowska (2016).
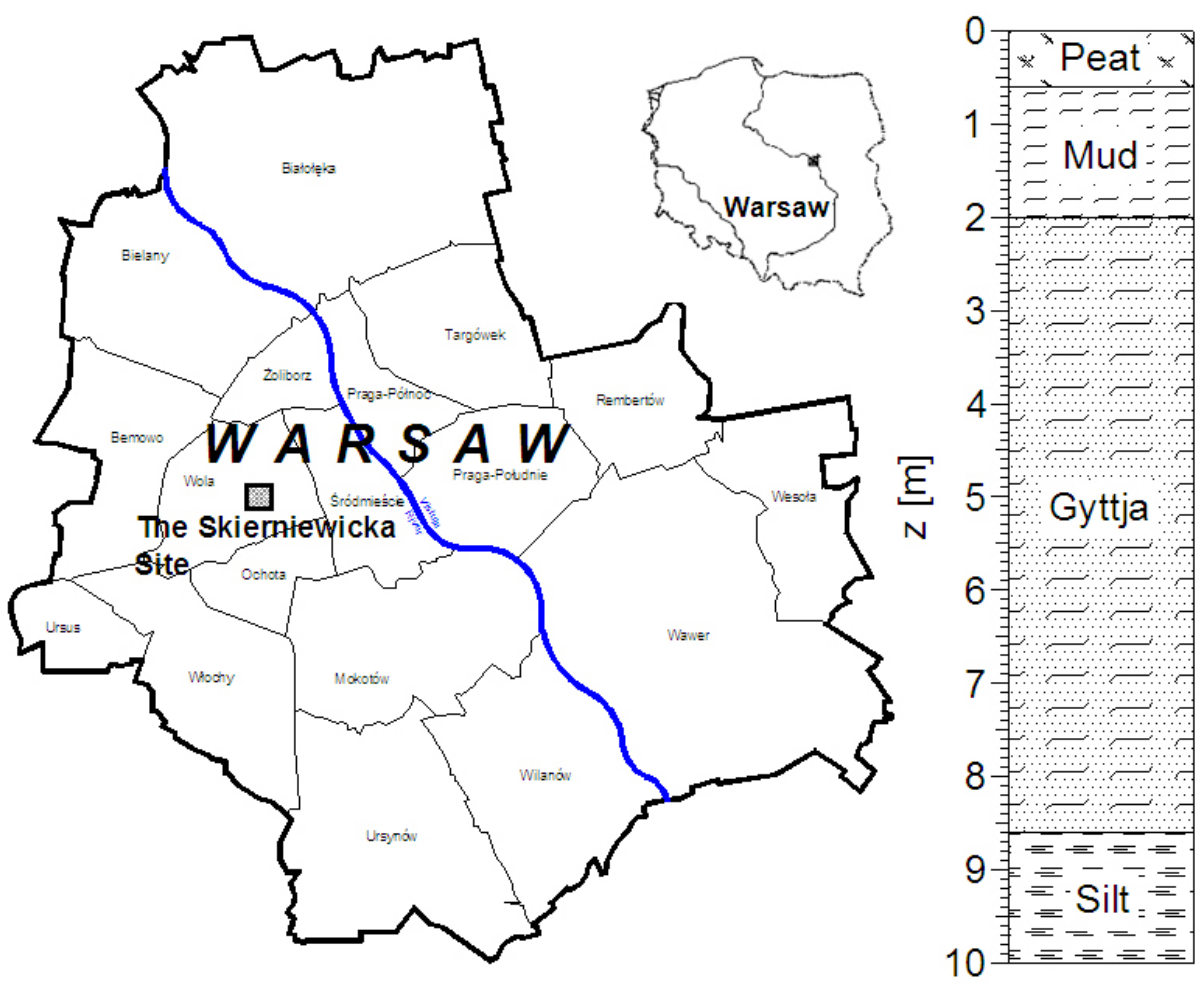

FIGURE 1. Location and typical cross-section of the test site 
To obtain the overconsolidation ratio from in situ test, the dilatometer test (DMT) was carried out in the analyzed subsoil.

The methodology of standard DMT test is widely known and detailed procedure for conducting the test has been presented by Marchetti (Marchetti 1980, Marchetti et al. 2001, Marchetti et al. 2008).

The value of the preconsolidation pressure is usually determined based on the results of oedometer tests. The preconsolidation pressure $\left(\sigma_{p}^{\prime}\right)$ can be also determined from DMT data according to formula (Mayne 1995):

$$
\sigma_{p}^{\prime}=0.51\left(p_{0}-u_{0}\right)
$$

where:

$p_{0}$ - corrected DMT contact pressure; $u_{0}$ - hydrostatic water pressure.

In situ tests, e.g. dilatometer tests, which can characterize the variation of $O C R$ with depth are valuable tools for geotechnical engineers.

Using the correlation between the overconsolidation ratio $(O C R)$ and the lateral stress index $\left(K_{D}\right)$ for soils with the material index $\left(I_{D}\right)$ bigger than 2.0 and for cohesive soils where the material index $\left(I_{D}\right)$ is smaller than 1.2 , the following correlations were proposed by Marchetti (1980):

$$
\begin{aligned}
& O C R=\left(0.67 \cdot K_{D}\right)^{1.91} \\
& O C R=\left(0.5 \cdot K_{D}\right)^{1.56}
\end{aligned}
$$

It is important to note that the estimation of the overconsolidation ratio from dilatometer tests depends on empirical and local experience. Many studies have been performed to improve the original correlations proposed by Marchetti. However, they were mostly limited to mineral soils.

Experience from organic soils indicates that the relation between the overconsolidation ratio $(O C R)$ and the lateral stress index $\left(K_{D}\right)$ is as follows (Lechowicz 1997):

$$
O C R=\left(0.45 \cdot K_{D}\right)^{1.40}
$$

To determine the overconsolidation ratio from laboratory test, the automatic oedometer test (ACONS) was carried out in the analyzed subsoil.

To determine the preconsolidation pressure or vertical yield stress the relationship between the stress and strain was used. The preconsolidation pressure and then overconsolidation ratio were obtained when the primary consolidation transitions to secondary compression with the time called $t_{a}$ (Malinowska 2016). And the vertical yield stress and then yield stress ratio were obtained when the soil under long-time compression was noticed, during the tertiary compression.

There were several methods used to estimate preconsolidation pressure and vertical yield stress. The Tavenas et al. (1979), Sridharan et al. (1991), and Senol new methods (Senol and Saglamer 2000) are the direct determination methods, whereas Casagrande (1936), Van Zelst (1948), Schmertmann (1953) and Sällfors (1975) are the graphical ones.

Thelaboratory methods were described by Bajda and Malinowska (2016). 


\section{RESULTS}

To receive the overconsolidation ratio from the laboratory tests the preconsolidation pressure under effective
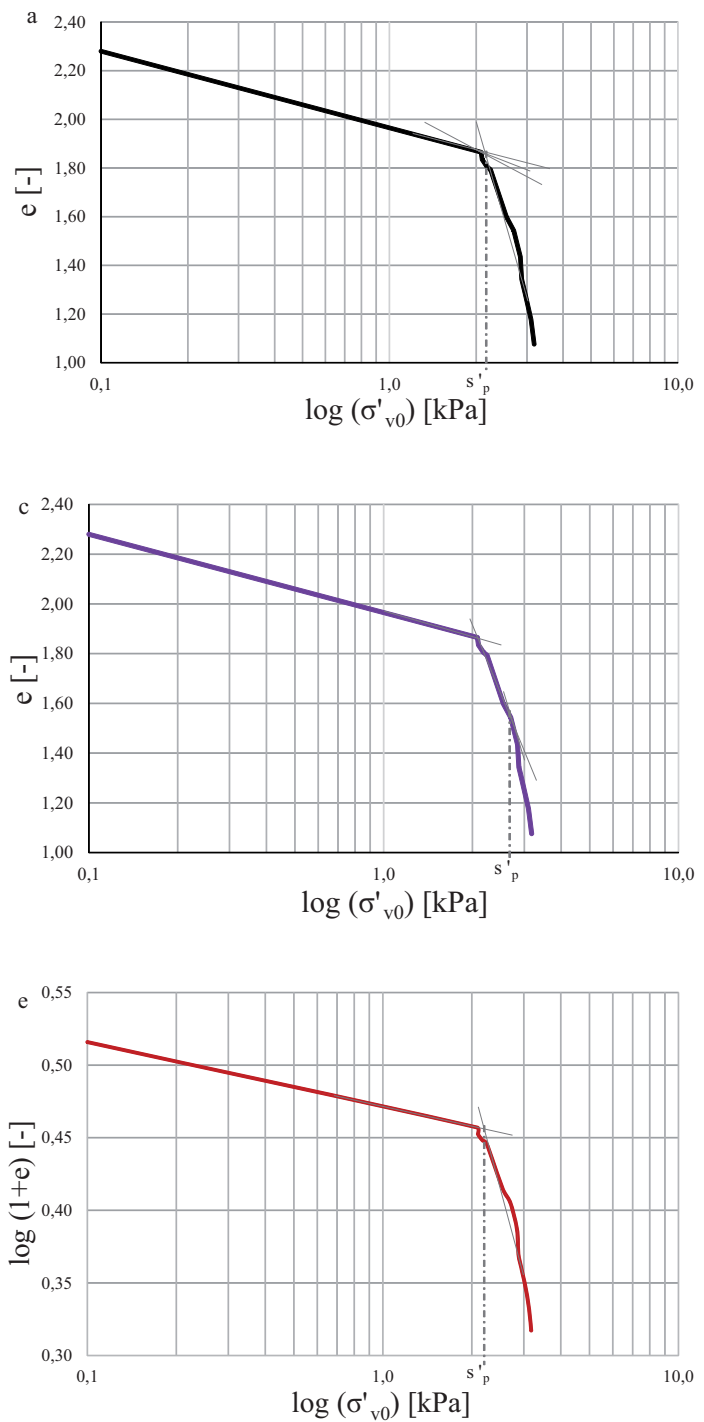

vertical stress were performed first. There are some results presented in Figure 2.

To receive the yield stress ratio from the laboratory tests the vertical yield
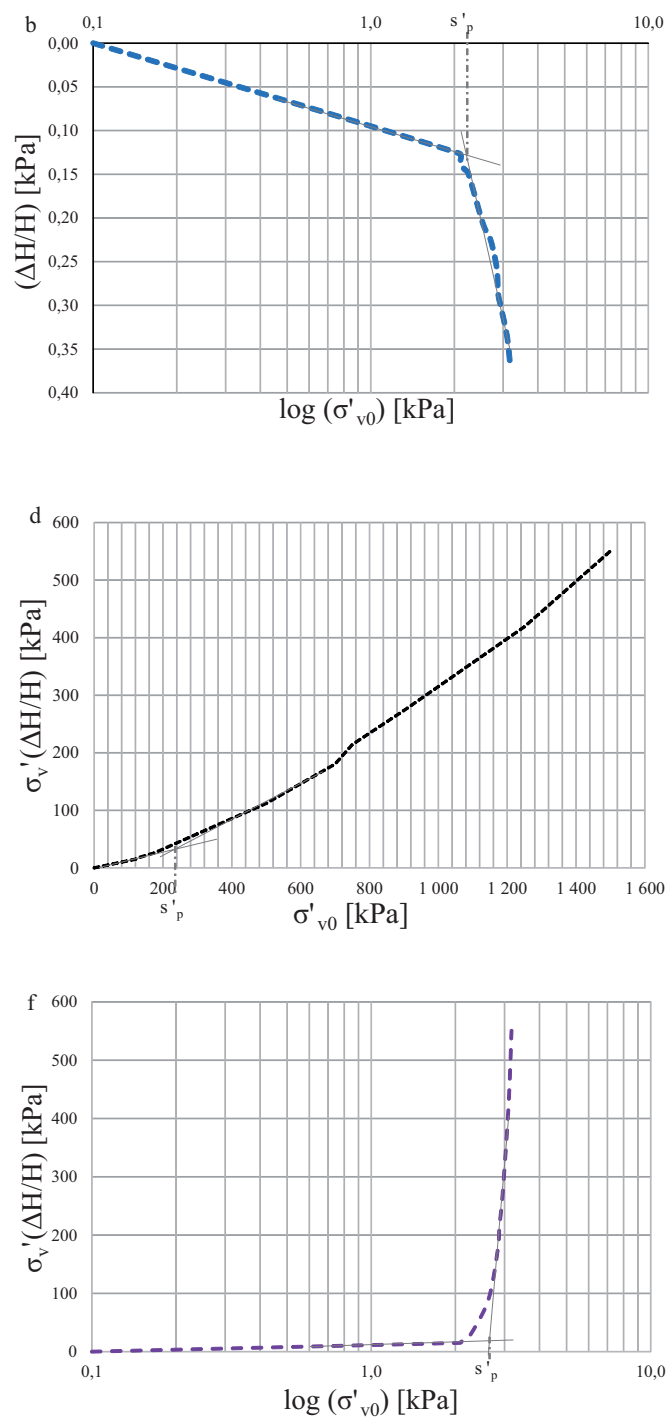

FIGURE 2. Methods for determination the preconsolidation pressure: a - the Casagrande method (1936); b - the Van Zelst method (1948); c - the Schmertmann method (1953); d - Tavenas et al. method (1979); e - Sridharan et al. method (1991); f - the Senol and Saglamer method (2000) 
stress under effective vertical stress for long-time period were performed first. The time was so long to match the secondary and tertiary compression of eemian gyttja. There are some results presented in Figure 3. Using equations
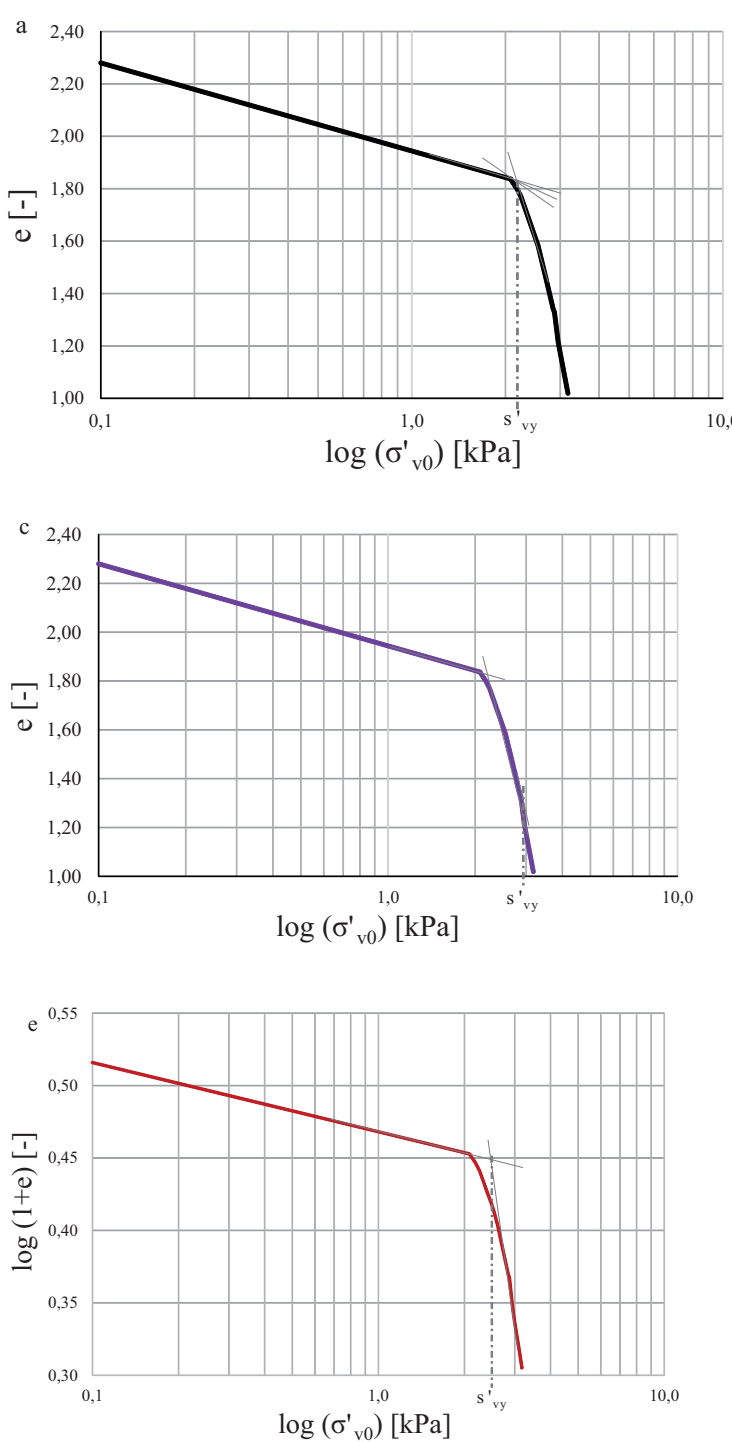

(4) and (5), the in situ test results were obtained (Fig. 4). The comparison of vertical yield stress and yield stress ratio with the preconsolidation pressure and overconsolidation ratio for eemian gyttja are presented in Table 2.
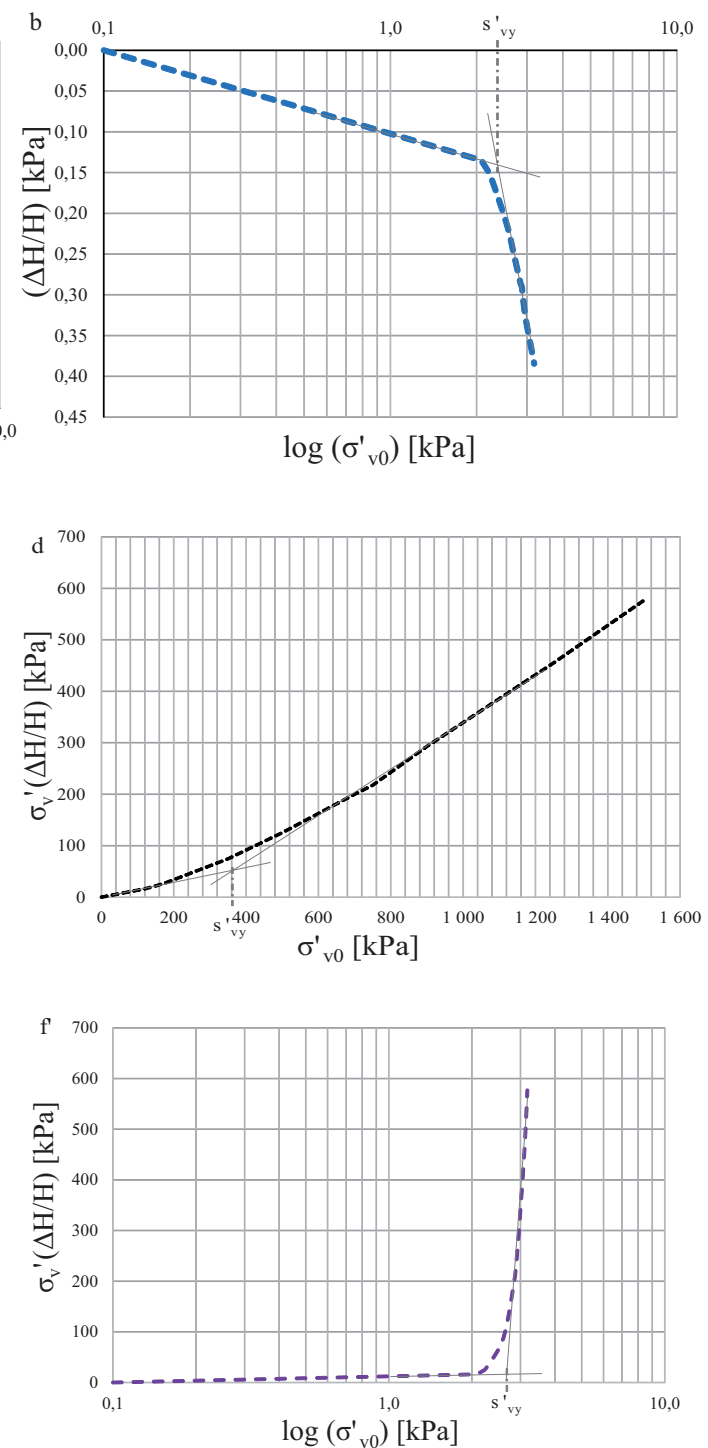

FIGURE 3. Methods for determination the vertical yield stress: a - the Casagrande method (1936); b - the Van Zelst method (1948); c - the Schmertmann method (1953); d - Tavenas et al. method (1979); e - Sridharan et al. method (1991); f - the Senol and Saglamer method (2000) 


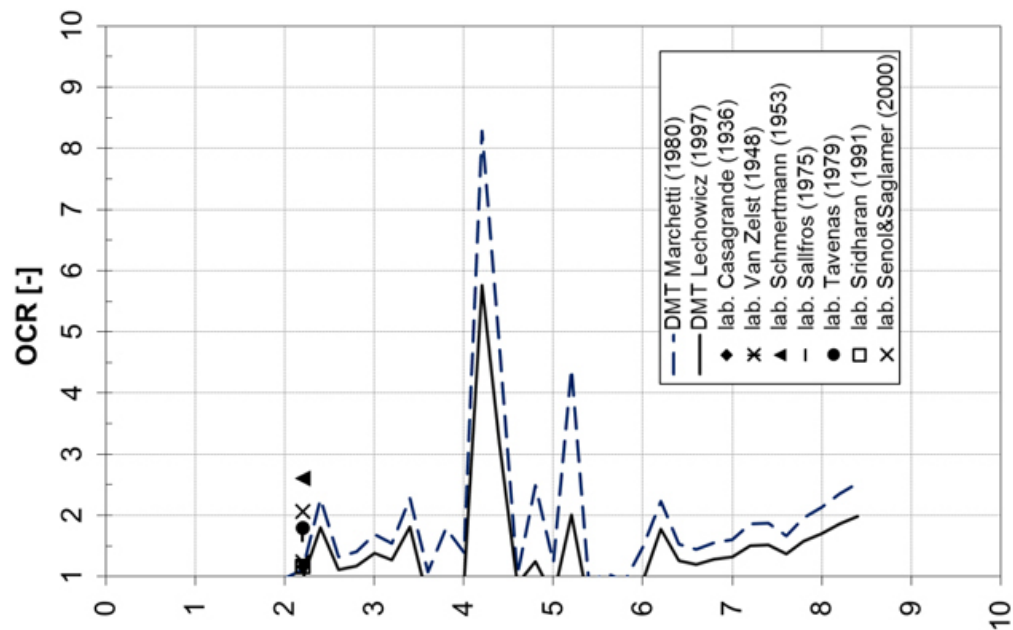

[u] z

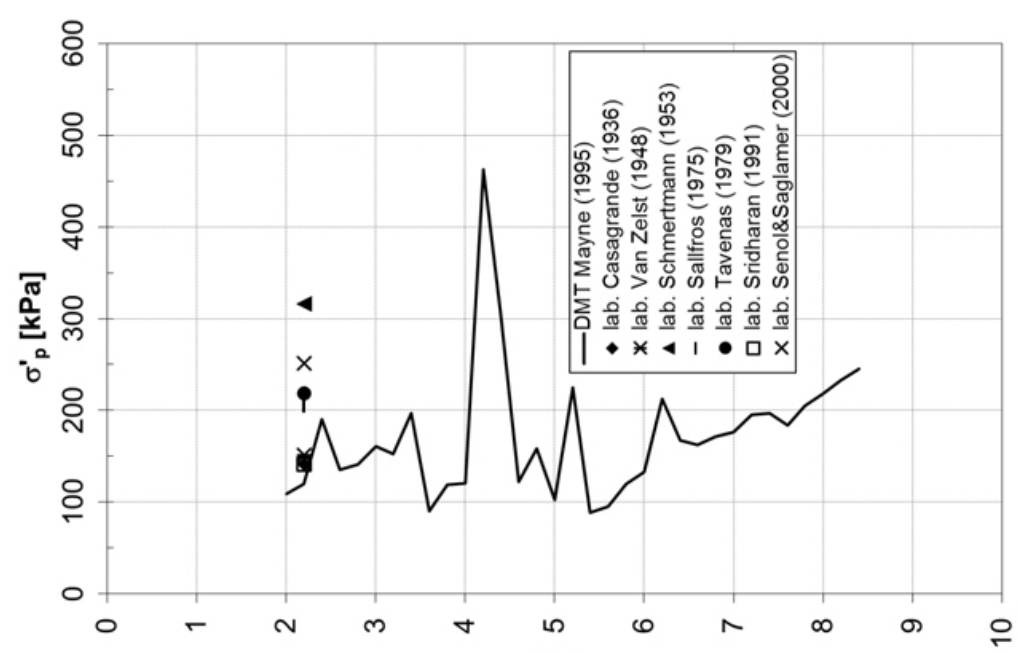

[u] z 
TABLE 2. The results of used method's for obtaining the vertical yield stress and yield stress ratio $(Y S R)$ and the preconsolidation pressure and overconsolidation ratio $(O C R)$

\begin{tabular}{|l|c|c|c|c|}
\hline Methods & $\begin{array}{c}\sigma_{v y}^{\prime} \\
(\mathrm{kPa})\end{array}$ & $\begin{array}{c}Y S R \\
(-)\end{array}$ & $\begin{array}{c}\sigma_{p}^{\prime} \\
(\mathrm{kPa})\end{array}$ & $\begin{array}{c}\text { OCR } \\
(-)\end{array}$ \\
\hline Casagrande method & 141 & 1.17 & 141 & 1.17 \\
\hline Van Zelst method & 182 & 1.50 & 151 & 1.25 \\
\hline Schmertmann method & 794 & 5.56 & 316 & 2.61 \\
\hline Sällfors method & 215 & 1.78 & 205 & 1.69 \\
\hline Tavenas method & 280 & 2.31 & 218 & 1.80 \\
\hline Sridharan method & 251 & 2.08 & 141 & 1.17 \\
\hline Senol and Saglamer method & 316 & 2.61 & 251 & 2.62 \\
\hline \multirow{2}{*}{ DMT } & - & - & 120 & $1.11^{*}$ \\
\cline { 2 - 5 } & - & - & - & $1.00^{* *}$ \\
\hline
\end{tabular}

Source: *Marchetti (1980), ** Lechowicz (1997).

\section{SUMMARY AND CONCLUSIONS}

In the laboratory the preconsolidation pressure or the vertical yield stress are obtained first, and then the overconsolidation ratio and yield stress ratio are calculated. In the in situ tests the overconsolidation ratio is obtained directly from the SDMT tests but the correlations presented in the literature are regional and cannot be used uncritically. A comparison between results obtained from SDMT tests and laboratory tests has been made.

The following conclusions can be drawn from the laboratory and in situ test results:

- from the laboratory test results the overconsolidation ratio is between 1.17 and 2.62 and the yield stress ratio is between 1.17 and 5.56;

- from the in situ test results the overconsolidation ratio has been obtained using some formulas and the values are between 1.0 and 1.11.
General, the values of the overconsolidation ratio received by using empirical formulas on the basis of SDMT results differs from values obtained on the basis of oedometer tests and are a little smaller.

The relationship between void ratio and logarithm of the vertical effective stress seems to be the most accurate for determination of the preconsolidation pressure and the vertical yield stress ratio, that includes the mechanical parameters such as secondary and tertiary compressibility and aging.

The yield stress ratio is higher than overconsolidation ratio. It might be caused by the secondary and tertiary compression that is visible in the eemian gyttja.

For further studies, the cementation, temperature change and other parameters should be considered for obtaining the yield stress ratio. 


\section{REFERENCES}

BAJDA M., MALINOWSKA E. 2016: Ocena parametrów odkształceniowych gytii na podstawie badań terenowych i laboratoryjnych. Acta Sci. Pol. Architectura 15 (3): 17-30.

BAJDA M., MALINOWSKA E. 2017: Determination the overconsolidation ratio of eemian gyttja. Ann. Warsaw Univ. Life Sci. SGGW, Land Reclam. 49 (3): 213-221.

BAJDA M., SKUTNIK Z. 2010: Determination of mechanical parameters of organic soil using CPT and SCPT. In: Proceedings of the 15th Danube-European Conference on Geotechnical Engineering: From research to design in European practice: Bratislava, Slovakia, Bratislava: Slovak University of Technology: 1-8.

BJERRUM L., LO K.Y. 1963: Effect of ageing on the shear-strength properties of a normally consolidated clay. Géotechnique 13 (2): 147-156.

BURLAND J.B. 1990: On the compressibility and shear strength of natural clays. Géotechnique 40 (3): 327-378.

CASAGRANDE A. 1936: Determination of the Preconsolidation Load and its Practical Significance. In: Proceedings of 1st International Conference on Soil Mechanics and Foundation Engineering, Cambridge, MA. Vol. 3: 60-64.

LAMBE T.W., WHITMAN R.V. 1969: Soil mechanics. Wiley, New York.

LECHOWICZ Z. 1997: Undrained shear strength of organic soils from dilatometer test. Ann. Warsaw Agricult. Univ. SGGW, Land Reclam. 28: 97-105.

LECHOWICZ Z., BAJDA M., RABARIJOELY S., WRZESINSKI G. 2014: Use Of SDMT for the evaluation of the geotechnical parameters of organic soils. In: Z. Młynarek, J. Wierzbicki (Eds.), CPTU and DMT in soft clays and organic soils: Wydawnictwo Exemplum, Poznan: 107-118.

LIPIŃSKI M.J., WDOWSKA M. 2014: Wybrane standardy określania parametrów geotechnicznych na podstawie badań laboratoryjnych. Acta Sci. Pol. Architectura 13 (1): 73-89.

LIPIŃSKI M.J., WDOWSKA M. 2017: A new method for evaluation of yield stress in cohesive soils. In: Proceedings of the 19th International Conference on Soil Mechanics and Geotechnical Engineering, Seoul: 435-438.
MALINOWSKA E.E. 2016: Tertiary compression of Polish peat. Prz. Nauk. Inż. Kszt. Środ. 25 (4): 507-517.

MARCHETTI S. 1980: In Situ Tests by Flat Dilatometer. J. Geotech. Eng. Div. ASCE 106, GT3. Proc. Paper 15290: 299-321.

MARCHETTI S., MONACO P., TOTANI G., CALABRESE M. 2001: The flat dilatometer test (DMT) in soil investigations. A report by the ISSMGE Committee TC16. In: Proceedings of International Conference on In-Situ Measurement of Soil Properties \& Case Histories [In-Situ 2001], Bali, Indonesia: 41.

MARCHETTI S., MONACO P., TOTANI G., MARCHETTI D. 2008: In Situ Tests by Seismic Dilatometer (SDMT). In: Proceedings from Research to Practice in Geotechnical Engineering, ASCE Geotech. Spec. Publ. 180: 292-311.

MAYNE P.W. 1995: Profiling yield stresses in clays by in-situ tests. In: Transportation Research Record 1479. National Academy Press, Washington, D.C.: 43-50.

PN-EN ISO 14688. Rozpoznanie i badania geotechniczne. Oznaczanie i klasyfikowanie gruntów. Część 1: Oznaczanie i opis [Geotechnical diagnosis and research. Determination and classification of soils. Part 1: Determination and description].

SÄLLFORS G. 1975: Preconsolidation pressure of soft, high-plastic clays. PhD thesis, Chalmers University of Technology, Göteborg [typescript].

SCHMERTMANN J.H. 1955: Undisturbed Consolidation Behaviour of Clay. Trans. ASCE 120 (2775): 1201-1233.

SCHMERTMANN J.H. 1991: The mechanical aging of soils. J. Geotech. Eng. 117 (9): 1288-1330 .

SENOL A., SAGLAMER A. 2000: Determination of Preconsolidation Pressure with a New Strain Energy-Log Stress Method. EJGE 5: 1-5.

SRIDHARAN A., ABRAHAM B.M., JOSE B.T. 1991: Improved technique for Estimation of Pre-Consolidation Pressure. Géotechnique 41 (2): 263-268.

STRÓŻYK J. 2015: The overconsolidation ratio of the Poznan clays from the area of SW Poland. World Multidisciplinary Earth Symposium. Proc. Earth Planet. Sci. 15: 293-298. 
SZCZEPAŃSKI T. 2007: OCR a YSR, czyli klasyczne i współczesne poglądy na prekonsolidacje gruntów spoistych. Przegl. Geol. 55 (5): 405-410.

SZYMAŃSKI A. 2000: The assessment of overconsolidation ratio in glacial soils on the basis of cone penetration tests. Ann. Warsaw Agricult. Univ., Land Reclam. 29, 51-62.

TAVENAS F., Des ROSIERS J.P., LEROUEIL S., La ROCHELLE P., ROY M. 1979: The Use of Strain Energy as a Yield and Creep Criterion for Lightly Overconsolidated Clays. Géotechnique 29 (3): 285-303.

URBAITIS D., LEKSTUTYTE I., GRIBULIS D. 2016: Overconsolidation Ratio Determination of Cohesive Soil. In: Proceedings of 13th Baltic Sea Geotechnical Conference Geotechnical Problems in Baltic Sea Region: 108-113. http://doi.org/10.3846/13bsgc.2016.014

Van ZELST T.W. 1948: An Investigation of the Factors Affecting Laboratory Consolidtion of Clay. Proceedings of the 2nd International Conference on Soil Mechanics and Foundation Engineering, Rotterdam. Vol. 7: 52-61.

Streszczenie: Ocena wspótczynnika uplastycznienia $i$ wspótczynnika prekonsolidacji gytii eemskiej. Naprężenie prekonsolidacji jest ważnym parametrem geotechnicznym, które określa zakres obciążeń wywieranych w przeszłości na podłoże gruntowe. Współczynnik prekonsolidacji $(O C R)$ jest jednym $\mathrm{z}$ głównych kryteriów zachowania się gruntu pod obciążeniem. Parametry te powinny być przede wszystkim określane dla gruntów o znanej historii geologicznej, czyli o spodziewanej wartości stopnia prekonsolidowania $\mathrm{z}$ dobrze rozpoznaną historią obciążeń geologicznych (np. nadkład, obciążenie lodowcem). Współczynnik uplastycznienia (YSR) jest wykorzystywany do określenia wartości naprężenia prekonsolidacji wynikającego z nadkładu, który może być zmieniony przez wiele procesów, takich jak ściśliwość wtórna i trzeciorzędowa, cementacja, starzenie, zmiana temperatury i inne. Współczynnik uplastycznienia $(Y S R)$ definiuje się jako stosunek pionowego naprężenia uplastycznienia $\left(\sigma_{v v}^{\prime}\right)$ do efektywnego naprężenia pionowego $\left(\sigma_{v 0}^{\prime}\right)$. W celu określenia pionowego naprężenia uplastycznienia i współczynnika uplastycznienia przeprowadzono w laboratorium badania w automatycznym edometrze. W ramach badań terenowych wykonano badanie dylatometryczne (DMT). Dokonano porównania między obliczonym współczynnikiem uplastycznienia, współczynnikiem prekonsolidacji gytii eemskiej z laboratorium a współczynnikiem prekonsolidacji $\mathrm{z}$ badań terenowych. Badania wykazały, że wartości współczynnika prekonsolidacji wyznaczone na podstawie badań laboratoryjnych są większe od wyznaczonych na podstawie badań in situ.

Słowa kluczowe: wskaźnik prekonsolidacji, współczynnik uplastycznienia, gytja eemska

\section{$M S$ received 22.02.2018 \\ MS accepted 04.06.2018}

\section{Authors' addresses:}

Edyta E. Malinowska

Laboratorium - Centrum Wodne

Szkoła Główna Gospodarstwa Wiejskiego

w Warszawie

ul. Ciszewskiego 6, 02-776 Warszawa

Poland

e-mail: edyta_malinowska@sggw.pl

Marek Bajda

Katedra Geoinżynierii

Wydział Budownictwa i Inżynierii Środowiska

Szkoła Główna Gospodarstwa Wiejskiego

w Warszawie

ul. Nowoursynowska 159, 02-776 Warszawa

Poland

e-mail: marek_bajda@sggw.pl 